\title{
PENGARUH TERAPI BEKAM TERHADAP KADAR KOLESTEROL DI RUMAH SEHAT IBNU SINA PALEMBANG TAHUN 2021
}

\author{
Lily Marleni ${ }^{1 *}$, Apriani ${ }^{2}$, Tafdhila ${ }^{3}$ Andilau $^{4}$ \\ 1,3 Prodi D-III Keperawatan, STIK Siti Khadijah Palembang \\ Jalan Demang Lebar Daun Lorok Pakjo, Palembang, Indonesia \\ ${ }^{2,4}$ Prodi Ilmu Keperawatan, STIK Siti Khadijah Palembang \\ Jalan Demang Lebar Daun Lorok Pakjo, Palembang, Indonesia \\ *e-mail:lilyasheeqa@gmail.com
}






\section{PENDAHULUAN}

Kolesterol sebenarnya bukan suatu penyakit namun merupakan salah satu komponen lemak, yaitu suatu molekul lemak yang terdapat di dalam sel. Kolesterol ini dibagi menjadi kolesterol LDL (Low Density Lipoprotein), kolesterol HDL (High Density Lipoprotein), total kolesterol dan trigliserida. Dalam tubuh manusia, disamping zat gizi lain seperti karbohidrat, protein, vitamin dan mineral, lemak merupakan salah satu zat gizi yang sangat diperlukan. Lemak merupakan salah satu sumber energi yang memberikan kalori paling tinggi. Disamping sebagai salah satu sumber energi, sebenarnya lemak khususnya kolesterol, merupakan zat yang sangat dibutuhkan oleh tubuh. Kolesterol merupakan bahan dasar pembentukan hormon-hormon steroid. Kolesterol juga berperan penting dalam membentuk membran sel, prekursor sintesis hormon steroid, hormon korteks adrenal, sintesis asam, asam empedu dan vitamin D. ( Umar, 2012).

Organisasi kesehatan dunia (world health organization / who) mengestimasikan saat ini prevalensi hiperkolesterolemia di dunia sekitar 45\%, di asia tenggara sekitar $30 \%$ (global health observatory data, 2019).

Menurut data rikesdas pada tahun 2018, prevalensi kadar kolesterol total di indonesia pada penduduk umur $>15$ tahun menurut karakteristik sebesar 7,6\% dengan jumlah 34,820 penduduk (kemenkes, RI. 2019).

Presentase kolesterol tinggi yang tercatat di pos pembinaan terpadu (posbindu) dan puskesmas yang sudah menggunakan sistem informasi surveilans ptm menurut jenis kelamin pada laki-laki sebesar $48 \%$ sedangkan perempuan $54,3 \%$. menurut data provinsi sumsel di indonesia tahun 2016 jumlah kolesterol tinggi sebesar 24,5\% (kemenkes, ri. 2017).

Pengobatan kadar kolesterol tinggi secara farmakologis dapat dilakukan dengan pemberian berbagai obat normolipiddemia diantaranya golongan obat statin, fibrat, resin, inhibitor absorpsi kolesterol selektif dan asam nikotinat. pengobatan farmakologis tersebut bergantung pada pertimbangan klien termasuk mengenai biaya, karakteristik demografi, penyakit penyerta, dan kualitas hidup. pengobatan hiperkolesterolemia saat ini belum efektif karena hampir $70 \%$ pasien hiperkolesterolemia di indonesia gagal mencapai sasaran kadar kolesterol sesuai dengan panduan pengobatan, salain itu pula karena harga obatnya relatif mahal, sering terjadi kekambuhan dan menimbulkan efek samping yang lebih berbahaya (price, 2013).

Selain pengobatan farmakologis, terdapat pengobatan alternatif komplementer. salah satunya yaitu terapi bekam. bekam merupakan salah satu praktik kedokteran islam (thibbun nabawi). bekam dalam bahasa arab disebut hijamah, hijamah merupakan teknik pengobatan sunnah rasulullah saw yang telah dipraktikkan oleh manusia sejak zaman dahulu. pengobatan hijamah pada saat ini dengan menggunakan alat yang praktis dan efektif dan cairan interstisial yang tertahan di bagian dalam kulit yang terangkat (sayed, 2013).

Hiperkolesterolemia mempunyai perhatian penting untuk diatasi dengan berbagai terapi komplementer, salah satu terapi yang bisa dilakukan adalah terapi bekam. bekam merupakan yang sudah ada sejak 2000 tahun sebelum masehi, jauh sebelum nabi 
muhammad diutus sebagai syriat islam. bekam bukan tindakan membuang darah tetapi membuang sampah metabolisme yang disebut dengan causative pathological substances. dengan kata lain, bekam basah tidak mengurangi volume darah sirkulasi. darah yang keluar dari perlukaan adalah "bloodlike" yang sampah metabolisme kolesterol, eritrosit yang tua dan lain-lain (faizal, 2020).

Hasil penelitian yang dilakukan oleh faizal (2020) menunjukkan bahwa ada pengaruh terapi bekam terhadap kadar kolesterol dengan $\mathrm{p}$ value $=0,000(\mathrm{p}<0,05)$. terapi bekam pada pasien kolesterol dapat menurunkan kadar kolesterol secara signifikan. rata-rata kadar kolesterol sebelum dilakukan terapi bekam adalah 254,65 dengan standar deviasi 60,477. sedangkan rata-rata kadar kolesterol sesudah dilakukan terapi bekam 173,06 dengan standar deviasi 35,745.

Berdasarkan uraian di atas, maka peneliti tertarik untuk melakukan penelitian tentang pengaruh bekam terhadap kadar kolesterolemia.

\section{METODE PENELITIAN}

Desain penelitian yang digunakan yaitu metode kuantitatif dengan pendekatan Pre Experimenyang bertujuan untuk mengetahui Pengaruh terapi bekam terhadap kadar kolesterol di Rumah Sehat Ibnu Sina Palembang Tahun 2021 Desain penelitian yang digunakan adalah pendekatan One Group pretest - postest design (Nursalam, 2014).

Populasi pada penelitian ini adalah seluruh pasien dengan kadar kolesterol tinggi yang ada di Rumah Sehat Ibnu Sina Palembang yang melakukan terapi bekam. Pengumpulan data dilakukan dengan menggunakan Purposive Sampling dengan teknik penentuan sampel dengan pertimbangan tertentu atau seleksi khusus (Siyoto, 2015).
Penelitian ini menggunakan alat berupa kit set pemeriksaan kolesterol merk Easy Touch beserta Cholesterol Test Strips dan Lancet untuk melakukan pengukuran kadar kolesterol terhadap responden dengan tujuan untuk melihat perbedaan kadar kolesterol sebelum dan setelah melakukan terapi bekam dan alat ukur menggunakan lembar observasi untuk mengukur variabel kadar kolesterol sebelum dan setelah melakukan terapi bekam dengan menggunakan SOP terapi bekam. Dan menggunakan Alat bekam seperti cupping set, lancet pen, bak instrumen, dll.

Analisa ini digunakan untuk mengetahui pengaruh antara variabel independent dan variabel dependent. Adapun uji statistik yang digunakan dalam penelitian ini adalah Uji $\mathrm{T}$ dependen (paired t-test) jika distribusi data normal, dan menggunakan uji nonparametrik yaitu uji wilcoxon jika distribusi tidak normal dengan hasil analisis statistik didapatkan nilai $\mathrm{p}$ value $\leq 0,05$ berarti ada perbedaan, jika $p$ value $\geq 0,05$ berarti tidak ada perbedaan antara sebelum dan setelah dilakukan terapi bekam.

\section{HASIL PENELITIAN}

\section{Analisa Univariat}

Kadar Kolesterol Sebelum Dilakukan Terapi Bekam di Rumah Sehat Ibnu Sina Palembang Tahun 2021

Hasil penelitian menunjukan distribusi frekuensi responden menurut kadar kolesterol sebelum dilakukan terapi bekam terlihat pada tabel 4.4 .

\begin{tabular}{lcccc}
\hline \multicolumn{1}{c}{ Variabel } & Mean & SD & $\begin{array}{l}\text { Min- } \\
\text { Maks }\end{array}$ & 95\% CI \\
\hline $\begin{array}{l}\text { Kadar } \\
\text { kolesterol } \\
\text { sebelum } \\
\text { terapi bekam }\end{array}$ & 229,19 & 21,557 & $202-$ & $219,44-$ \\
\hline
\end{tabular}

Dari tabel 4.4, dapat dilihat bahwa dari 16 responden, rerata kadar kolesterol sebelum dilakukan terapi bekam sebesar 229,19 dan 
standar deviasi 21,557. Skor kadar kolesterol sebelum dilakukan terapi bekam terendah adalah 202 dan skor tertinggi adalah 267. Dari hasil estimasi interval dapat disimpulkan 95\% di yakini bahwa rerata kadar kolesterol sebelum dilakukan terapi bekam diantara 219,44 sampai dengan 239,37.

\section{Kadar Kolesterol Setelah Dilakukan Terapi Bekam}

Hasil penelitian menunjukkan distribusi frekuensi responden menurut kadar kolesterol setelah dilakukan terapi bekam dilihat dalam tabel 4.5 .

\begin{tabular}{ccccc}
\hline Variabel & Mean & SD & $\begin{array}{c}\text { Min- } \\
\text { Maks }\end{array}$ & $\mathbf{9 5 \%}$ CI \\
\hline $\begin{array}{c}\text { Kadar } \\
\text { kolesterol } \\
\text { setelah } \\
\text { terapi bekam }\end{array}$ & 229,19 & 21,557 & $202-$ & $219,44-$ \\
\hline
\end{tabular}

Dari tabel 4.5, dapat dilihat bahwa dari 16 responden, rerata kadar kolesterol setelah dilakukan terapi bekam sebesar 197,63 dan standar deviasi 21,587. Skor kadar kolesterol setelah dilakukan terapi bekam terendah adalah 168 dan skor tertinggi adalah 251. Dari hasil estimasi interval dapat disimpulkan $95 \%$ diyakini bahwa rerata kadar kolesterol setelah dilakukan tearapi bekam diantara 188,06 sampai dengan 208,31.

\section{Analisa Bivariat}

Pengaruh Kadar Kolesterol Sebelum dan Setelah dilakukan Terapi Bekam di Rumah Sehat Ibnu Sina Palembang Tahun 2021 $(\mathrm{N}=16)$

\begin{tabular}{llll}
\hline Variabel Mean & SD & $\begin{array}{l}95 \% \\
\text { CI }\end{array}$ & P Value
\end{tabular}

\begin{tabular}{llll}
\hline $\begin{array}{l}\text { Kadar } \\
\text { kolesterol }\end{array}$ & & & \\
sebelum & 229,19 & 21,557 & 218,69 \\
terapi & & & 240,25 \\
bekam & & & \\
\end{tabular}

\begin{tabular}{llll}
\hline Kadar & & & \\
kolesterol & & & $87,56-$ \\
setelah & 197,63 & 21,587 & 208,69 \\
terapi & & & \\
bekam & & &
\end{tabular}

Berdasarkan tabel 4.6, menunjukan bahwa rerata kadar kolesterol sebelum dilakukan terapi bekam adalah 229,19, standar deviasi adalah 21,557 dan 95\% CI kadar kolesterol sebelum dilakukan terapi bekam 218,69 - 240,25. Rerata kadar kolesterol setelah dilakukan terapi bekam adalah 197,63, standar deviasi yaitu 21,587 dan 95\% CI kadar kolesterol setelah dilakukan terapi bekam adalah 187,56 - 208,69. Berdaraskan uji statistik dengan menggunakan uji paired t-test didapatkan $\mathrm{p}$ value $=0,000$, dengan nilai $\alpha=$ $0,05(\mathrm{p}<\alpha)$, berarti ada perbedaan kadar kolesterol sebelum dan setelah dilakukan terapi bekam di Rumah Sehat Ibnu Sina Palembang Tahun 2021.

\section{PEMBAHASAN}

\section{Pembahasan Univariat \\ Kadar Kolesterol Sebelum dilakukan Terapi Bekam}

Hasil penelitian menunjukan bahwa rerata kadar kolesterol sebelum dilakukan terapi bekam sebesar 229,19 dan standar deviasi 21,557. Skor kadar kolesterol sebelum dilakukan terapi bekam terendah adalah 202 dan skor tertinggi adalah 267. Dari hasil estimasi interval dapat disimpulkan 95\% di yakini bahwa rerata kadar kolesterol sebelum dilakukan terapi bekam diantara 219,44 sampai dengan 239,37.

Perubahan pola hidup masyarakat yang serba modern dan praktis terutama wanita yang sudah dewasa sebagian besar enggan tidak melakukan pola hidup sehat. Dampak dari pola hidup yang tidak sehat mengakibatkan rasio antara tinggi dan berat badan tidak ideal. Pola hidup tidak sehat dan aktivitas fisik yang kurang, sehingga beresiko mengalami obesitas (Sinurat, 2019).

Kolesterol adalah salah satu komponen dalam membentuk lemak. Di dalam lemak terdapat berbagai macam komponen yaitu seperti zat trigliserida, fosfolipid, asam lemak bebas, dan juga kolesterol. Secara umum, kolesterol berfungsi untuk membangun dinding didalam sel (membran sel) dalam tubuh (Mumpuni, 2011).

Ada beberapa faktor yang menyebabkan peningkatan dalam kolesterol dalam tubuh, adanya ketidak normalan genetika yang dapat menaikan kolesterol dalam produksi kolesterol hati atau penurunan hati terhadap kemampuan dalam membersihkan kolesterol dari darah (Sabriah, 2015). 
Kolesterol yang beredar dalam peredaran darah berasal dari hati dan hanya sedikit yang bersumbar dari makanan. Minyak jenuh dan minyak trans yang masuk lewat mulut akan ditimbun di hati, kemudian oleh hati diolah menjadi kolesterol dalam jumlah yang berlebihan (Tandra, 2021).

Berdasarkan penelitian yang dilakukan oleh Faizal (2020) menunjukan bahwa rata-rata kadar kolesterol sebelum dilakukan terapi bekam adalah 254,65 dan standar deviasi sebesar 60,477 .

Berdasarkan hasil penelitian, teori penunjang dan penelitian terkait maka peneliti berpendapat bahwa rerata kadar koleserol sebelum dilakukan terapi bekam berada dalam keadaan yang tidak normal atau masuk dalam kategori tinggi. Hal ini disebabkan karena tingginya kadar kolesterol dalam darah apabila menerapkan pola makan yang mengandung lemak jenuh yang tinggi. Sering mengkonsumsi makanan berlemak akan menanbah kadar kolesterol yang meningkat karena kolesterol besumber dari makanan dan tubuh juga memproduksi kolesterol.

\section{Kadar Kolesterol Setelah Dilakukan Terapi Bekam}

Berdasarkan hasil penelitian didapatkan rerata kadar kolesterol setelah terapi bekam adalah 197,63 dan standar deviasi 21,587. Skor kadar kolesterol setelah dilakukan terapi bekam terendah adalah 168 dan skor tertinggi adalah 251. Dari hasil estimasi interval dapat disimpulkan $95 \%$ di yakini bahwa rerata kadar kolesterol setelah dilakukan terapi bekam diantara 188,06 sampai dengan 208,31.

Hasil penelitian ini sejalan dengan teori Hasina (2021), terapi bekam berperan menguranggi kadar lemak dan kolesterol berbahaya, dalam hal ini Low Density Lipid (LDL) dalam darah maupun yang mengendap di dinding pembuluh darah sehingga menguranggi penyumbatan pembuluh darah. Terapi bakam juga meningkatkan suplai darah ke lapisan dalam endothelium yang berperan memproduksi nitrit oksida (endothelium-derived relaxing factor) yang membantu peregangan dan pelebaran pembuluh darah. Penurunan kadar kolesterol total setelah diberikan terapi bekam dikarenakan terdapat beberapa efek dari pemberian terapi bekam melalui makanisme sistem hematologi yang memberikan efek utama melalui jalur sistem regulasi koagulan- antikoagulasi dengan peningkatan aliran darah dan oksigenasi organ. Bekam merupakan tindakan membuang sampah metabolisme yang disebut dengan cuasative pathological substances. Sehingga bekam tidak menguranggi volume darah sirkulasi. Darah yang keluar dari perlukaan darah "bloodlike" yang berasal dari sampah metabolisme kolesterol, eritrosit yang tua, dan lain-lain. Banyaknya darah bekam yang dilakukan secara benar tidak menguranggi haemoglobin. Terbentuknya barier kulit akan meningkatkan fungsi ekskresi kulit diantaranya mengeluarkan lipid dan subtansi yang upbersifat hidrofobik yang merupakan makanisme yang mendsari efek terapi bekam terhadap penurunan kadar kolesterol darah total.

Berdasarkan penelitian terkait yang dilakukan oleh Faizal (2020) menunjukan bahwa rata-rata kadar kolesterol setelah dilakukan terapi bekam adalah 173,06 dan standar deviasi sebesar 35,745.

Berdasarkan penelitian terkait yang dilakukan oleh Mainisasti (2019) menunjukan bahwa rerata kadar kolesterol setelah dilakukan terapi bekam adalah 124,59 dan standar deviasi sebesar 39,64

Berdasarkan hasil penelitian, teori penunjang dan penelitian terkait maka peneliti berpendapat bahwa dengan melakukan terapi bekam dapat menurunkan kadar kolesterol dalam tubuh. Hal ini disebabkan penghisapan darah dan mengeluarkannya dari kulit yang kemudian ditampung dalam gelas khusus yang menyebabkan penarikan dan penyedotan darah. Kemudian dilakukan penyayatan pada kulit dengan pisau atau jarum sehingga darah keluar untuk mengeluarkan racun oksidan dalam tubuh melalui goresan tipis pada pembuluh darah perifer pada lapisan epidemis.

\section{Pembahasan Bivariat}

\section{Pengaruh Terapi Bekan Terhadap Kadar Kolesterol}

Hasil penelitian menunjukan bahwa rerata kadar kolesterol sebelum dilakukan terapi bekam adalah 229,19, standar deviasi adalah 21,557. Pada 95\% CI kadar kolesterol sebelum dilakukan teraoi bekam 218,69 - 240,25. Kadar kolesterol setelah dilakukan terapi bekam adalah 197,63, standar deviasi yaitu 21,587. Pada 95\% CI kadar kolesterol setelah dilakukan terapi bekam adalah 187,56 - 208,69. Berdasarkan uji statistik dengan menggunakan paired t-test 
didapatkan $\rho$ value $=0,000$, dengan nilai $\alpha=$ $0,05(\rho<\alpha)$.

Kolesterol tinggi ini disebabkan oleh adanya unsur lembab panas dalam organ hati. Lembab panas yang berlebihan ini bisa merusak hati, lambung dan limpa yang bertanggung jawab terhadp aliran darah. Oleh karena itu, perlu dilakukan pembuangan unsur lembab panas dari hati, lambung dan limpa. Dalam hal ini bekam bisa dilakukan untuk membuang unsur lembab panas melalui proses pengeluaran darah. Selain itu untuk memperbaiki organ atau pembuluh darah yang rusak, bisa dilakukan proses stimulus organ dengan bekam. Bekam juga diharapkan bisa menormalkan kembali fungsi pembuluh darah yang penuh dengan plak-plak kolesterol melalui teori homeostasis (Umar, 2012).

Hasil penelitian ini sejalan dengan teori Hidayat (2018). Penurunan kadar kolesterol yang dipengaruhi intervensi terapi bekam diduga karena adanya pengaruh maknisme sistem hematologi yang memberikan efek utama melalui jalur sistem regulasi koagulasiantikoagulasi dengan peningkatan aliran darah dan peningkatan oksigenasi organ. Mengingat hepar merupakan tempat filtrasi darah dalam tubuh, melalui makanisme sistem imun inilah kadar kolesterol dalam tubuh dapat diturunkan. Adapun makanisme yang mendasari efek terapi bekam terhadap penurunan kadar kolesterol darah total, terbukanya barrier kulit akan meningkatkan fungsi eksresi kulit diantaranya mengeluarkan lipid dan subtansi/ material yang bersifat hidrofobik.

Titik bisa membantu memperbaiki aliran darah yang membawa kolesterol dan liver yang mengola kolesterol. Namun pada beberapa kasus dengan kadar kolesterol tinggitetap perlu obat medis agar kadar kolestrol segera menurun. Karena kolestrol tinggi tidak menimbulkan keluhan, maka bekam ditujukan untuk peredaran darah dan organ yang mengurusi darah, yaitu hati dan limpa (Faizal, 2020).

Berdasarkan penelitian terkait yang dilakukan oleh Faizal (2020) kadar kolesterol didapatkan mean sebelum terapi bekam adalah 254,65 dengan standar deviasi 60,477, dan mean setelah dilakukan terapi bekam adalah 173,06 dengan standar deviasi 35,745. Hasil analisa di dapatkan $\mathrm{p}$ value $=0,000(\mathrm{p}<0,05)$ sehingga ada perbedaan nilai rata-rata kadar kolesterol sebelum dan sesudah dilakukan terpai bekam.
Berdasarkan penelitian terkait yang dilakukan Meinisasti (2019) kadar kolestrol didapatkan mean sebelum dilakukan terpi bekam adalah 167,41 dengan standar deviasi 57,14, dan mean setelah dilakukan terapi bekam adalah 124,59 dan standar deviasi 39,64. Hasil ada perbedaan kadar kolesterol sebelum dan setelah terapi bekam $\mathrm{p}$ value $=0,003(\mathrm{p}<0,05)$.

Dari hasil penelitian teori penunjang dan penelitian terkait, maka peneliti berpendapat bahwa kadar kolesterol yang terjadi pada responden setelah dilakukan terapi bekam disebabkan titik terapi bekam dapat membantu memperbaiki aliran darah yang membawa kolesterol dan liver yang mengelola kolesterol.

Nabi dulu melakukan bekam untuk pengobatan, maka perkara bekam ini berbedabeda dan tidak disyariatkan meneladani Nabi dalam perkara ini, karena bekam masuk dalam pengobatan.

Ali bin Abi Thalib berkata, "Jibril datang kepada Nabi Muhammad SAW dengan perintah berbekam pada titik al-akhdain (urat leher) dan al-kahil (pundak)." (Al Dailami). Riwayat lain dari Shuhaib, Rasulullah bersabda, "Berbekamlah di tengah tengkuk karena hal itu dapat menyembuhkan 72 macam penyakit."

Aiman bin Abdul Fattah dalam Keajaiban Thibbun Nabawi: Bukti Ilmiah dan Rahasia Kesembuhan dalam Metode Pengobatan Nabawi menjelaskan, berdasarkan hasil tim laboratorium yang mengadakan penelitian darah yang keluar dari titik-titik bekam, ada beberapa hasil yang didapatkan. Pertama, terapi bekam melindungi dan sekaligus menguatkan unsur-unsur sistem kekebalan.

Kedua, proses bekam membuang sel-sel darah merah yang rusak dan darah yang tidak dibutuhkan lagi.

Ketiga, kapasitas ikatan zat besi dalam darah bekam tinggi sekali (550-1100). Satu hal yang menunjukkan bahwa bekam mempertahankan zat besi yang ada dalam tubuh tidak ikut keluar bersama darah yang dikeluarkan sehingga dapat membentuk sel-sel muda yang baru.

Keempat, kandungan sel darah merah atau sel darah putih dalam darah bekam tinggi sekali. Ini menunjukkan bahwa proses bekam berhasil mengeluarkan semua kotoran, sisa, dan endapan darah sehingga mendorong kembali aktifnya seluruh sistem dan organ tubuh. 


\section{SIMPULAN DAN SARAN}

Berdasarkan penelitian yang dilakukan di Rumah Sehat Ibnu Sina Palembang Tahun 2021 dapat disimpulkan sebagai berikut:

1. Rerata kadar kolesterol sebelum dilakukan terapi bekam sebesar 229,19 dan standar deviasi 21,557. Skor kadar kolesterol sebelum dilakukan terapi bekam terendah adalah 202 dan skor tertinggi adalah 267 .

2. Rerata kadar kolesterol setelah dilakukan terapi bekam sebesar 197,68 dan standar deviasi 21,587. Skor kadar kolesterol setelah dilakukan terapi bekam terendah adalah 168 dan skor tertinggi adalah 251 .

3. Ada pengaruh sebelum dan setelah dilakukan terapi bekam terhadap kadar kolesterol di Rumah Sehat Ibnu Sina Palembang Tahun 2021 ( $\mathrm{p}$ value = 0,000).

\section{Saran}

Diharapkan hasil penelitian ini dapat menambah acuan untuk meningkatkan pelayanan pada pasien dengan kolesterol tinggi yang berkaitan dengan terapi bekam dalam menurunkan kadar kolesterol dan memberikan pengetahuan dengan penyuluhan kepada pasien dengan kolesterol tinggi.

\section{DAFTAR PUSTAKA}

[1] Dahlan, M. Sopiyudin. (2010). Besar Sampel Dan Cara Pengambilan Sampel. Jakarta : Salemba Medika.

[2] Donsu, Jenita D. (2016). Metodologi Penelitian Keperawatan. Yogyakarta : PUSTAKA BARU PRESS.

[3] Faizal, K. M. (2020). Pengaruh Terapi Bekam Terhadap Kadar Koleaterol Di Rumah Sakit Bakti Timah Pangkal Pinang. Malahayati Nursing Journal, 259-267.

[4] Global Health Observatory Data. 2019. Raised Cholesterol: Situation and Trends. World Health Organization.

[5] Hasina, Siti Nur \& Haryani, Ellya Chandra. 2021. Terapi Bekam Berpengaruh Terhadap Penurunan Kadar Kolesterol Dalam Darah Total. Jurnal Keperawatan, Vol. 13, No.1, 11-8

[6] Hidayat, A. A. (2009). Penelitian Keperawatan dan Teknik Analisis Data. Jakarta: Selemba Medika.

[7] Hidayat, A. H. (2019). Khanzanah Terapi Komplementer Alternatif. Bndung: Nuansa Cendikia.

[8] Kementrian Kesehatan RI. 2017. Profil Penyakit Menular Tahun 2016. Jakarta: Kementrian Kesehatan RI, 2007.

[9] Kementrian Kesehatan RI. (2019). Laporan Nasional RISKESDAS 2018. Jakarta : Badan Penelitian dan Pengambangan Kesehatan.

[10] Laker, M. (2006). Memahami Kolesterol. Jakarta: PT Grafika Multi Warna.

[11] Meinisasti, R. (2019). Perbedaan Kolesterol Sebelum Dan Sesudah Terapi Bekam Basah Di Kota Bengkulu. Jurnal of Nursing and Public Health, 19-22.

[12] Mumpuni, Y., \& Wulandari, A. (2011). Cara Jitu Mengatasi Kolesterol. Yogyakarta : ANDI

[13] Murray, R. K., Granner, D. K., \& Rodwell, V. W (2013). Biokimia Harper. Edisi 27. Jakarta: EGC.

[14] Notoadmojo, S. (2012). Metodologi Penelitian Kesehatan (red av). Jakarta: Rineka Cipta.

[15] Nursalam. (2013). Metodologi Penelitian Ilmu Keperawatan : Pendekatan Praktis Edisi 3. Jakarta Selatan: Selemba Medika.

[16] Nursalam. (2014). Metodologi Penelitian Ilmu Keperawatan : Pendekatan Praktis Edisi 3. Jakarta Selatan : Salemba Medika.

[17] PBI. (2018). Panduan Pengajaran Bekam. Jakarta.

[18] Price, S. A., \& Wilson, L. M. (2013). Fatofisiologi Konsep Klinis Prosesproses Penyakit. Jakarta: EGC. 
[19] Rahmadi, A (2019). BekamTinjauan Hadis dan Medis. Tanggerang Selatan: Pustaka Pedia.

[20] Ridho, A. A. (2015). Bekam Sinergi. Solo: Aqwamedika.

[21] Sabriah, Aisyah Nayla. 2015. Cara Ampuh Menrunkan Kolesterol Dalam Sekejab. Jakarta : Lembar Langit Indonesia.

[22] Sinurat, Radot Ganda. 2019. Hubungan BMI dengan Kadar Kolesterol Total Darah pada wanita dewasa. jurnal Online, Vol.3, No.2, 21-30.

[23] Sutanto. (2010). Cekal (Cegah \& Tangkal) Penyakit Modern
Hipertensi, Stroke, Jantung, Kolesterol, dan Diabetes. Yogyakarta : ANDI

[24] Tandra, Hans. 2021. Kolesterol \& Trigliserida. Jakarta : PT. Gramedia Pusstaka Utama.

[25] Toha, Ap. H. A. (2010). Ensiklopedia Biokimia dan Biologi Molekuler. Jakarta: EGC.

[26] Umar, W. A. (2012). Bekam Untuk 7 Penyakit Kronis. Solo: Thibbia.

[27] Umar, W. A. (2019). Bekam Medik. Sukoharjo: Thibbia.

[28] Yovina.S, 2012. Kolesterol. Yogyakarta : Pinang Merah Publisher. 